\title{
FAKTOR YANG BERHUBUNGAN DENGAN KECELAKAAN KERJA PADA PERAWAT DI RUMAH SAKIT JIWA TAMPAN PEKANBARU TAHUN 2015.
}

\author{
ARDENNY* \\ *Dosen Jurusan Keperawatan Poltekkes Kemenkes Riau
}

\begin{abstract}
ABSTRAK
Work accident is an event that is not thought to backfire and all that can cause human casualties or property (Permenaker No. 03/MEN/1998). Demand management of occupational health and safety program at the Hospital (K3RS) higher for workers, visitors of patients, and society About a hospital wants to get protection from health problems and accidents, whether as a result of the process of service delivery as well as the condition of facilities and infrastructure in the hospital that do not meet the standards. The purpose of this study was to determine the factors associated with workplace accidents in nurses. This study uses observational study design, with a cross-sectional design that was conducted in April-May 2015 in Pekanbaru Handsome Mental Hospital. Total samples 121 people. Measuring instruments used are questionnaires and observation sheets. Analiais data used is the Chi-Square test. The results showed that the variables associated with school performance is variable age ( $p$ value 0.000), knowledge ( $p$ value 0.004), attitude ( $p$ value 0.014), and action ( $p$ value 0.005). It is suggested that the hospital through the training for mengedakan porgram K3RS in providing mental health pelayaanan Handsome Peknbaru Psychiatric Hospital.
\end{abstract}

Keywords: Knowledge, attitudes, actions, age

\section{PENDAHULUAN}

Berdasarkan

nomor 1 tahun 1970 tentang keselamatan kerja yang bertujuan untuk memberikan perlindungan bagi karyawan dan masyarakat umum. Undang-undang ini tidak menghendaki sifat kuratif atau korektif atas kecelakaan kerja, melainkan kecelakaan kerja harus di cegahjangan sampai terjadi dan lingkungan kerja harus memenuhi syarat-syarat kesehatan. Tuntutan pengelolaan program kesehatan dan keselamatankerja di Rumah Sakit (K3RS) semakin tinggi karena pekerja, pengunjung pasien, dan masyarakat sekitar RumahSakit inginmendapatkan perlindungan dari gangguan kesehatan dan kecelakaan kerja, baik sebagai dampak proses kegiatan pemberian pelayanan maupun karena kondisi sarana dan prasarana yang ada di Rumah Sakit yang tidak memenuhi standar (Kemenkes No. 1078/2010).

Masalah perilaku kekerasan pasien hampir selalu terjadi di ruang perawatan jiwa. Beberapa riset menunjukkan bahwa perawat jiwa sering mengalami kekerasan dari klien (Fight, 2002;Nijman, Foster, dan Bowers, 2007)

Menurut penelitian Witodjo dan Widodo (2008) di Rumah Sakit Jiwa Surakarta diketahui bahwa angka kejadian kekerasan di ruang kresna 
tahun 2004 sebanyak 43 klien atau $15,7 \%$ ). Klien yang dirawat di ruangan Model Praktek Keperawatan Profesional (MPKP) Kresna mendapatkan pelayanan komunikasi terapeutik sesuai standar. Sedangkan klien yang dirawat selain di ruang Kresna yang kurang mendapatkan komunikasi terapeutik sesuai standar operasional prosedur, sebanyak 230 klien atau 84,3\%.

Menurut peneliti Veny Elita, dkk (2010) terhadap 61 orang perawat tentang kejadian tindakan kekerasan oleh pasien di ruang rawat inap jiwa RSJ Tampan, diperoleh data kekerasan fisik yang dilakukan pasien pada diri sendiri (84\%) merupakan bentuk perilaku kekerasan yang paling sering terjadi di ruang rawat inap jiwa. Kemudian diikuti dengan kekerasan berupa ancaman fisik kepada perawat $(79 \%)$, penghinaan kepada perawat $(77 \%)$ dan kekerasan verbal (70\%). Lebih dari separuh responden $(51 \%)$ melaporkan mengalami kekerasan fisik yang berakibat cedera ringan dalam satu tahun terakhir. Dan sebagian kecil responden $(20 \%)$ melaporkan pernah mengalami kekerasan fisik yang menyebabkan cedera serius

Studi pendahuluan yang dilakukan di RS Jiwa Tampan di dapatkan data bahwa RS Jiwa Tampan mempunyai beberapa ruangan rawat inap, diantaranya adalah, Unit Perawatan Intensif Psikiatri (UPIP), ruangan Kuantan, ruangan Indragiri, yang merupakan ruangan gaduh gelisah (intermediate). Jumlah tenaga perawat yang ada di 8 ruangan dirumah sakit jiwa tampan sebanyak 121 .

Hasil wawancara langsungdari Ketua Komite Keperawatan Rumah Sakit Jiwa dan lima perawat yang menangani pasien jiwa sering terjadinya benturan fisik antara perawat dengan pasien jiwa terutama di ruang UPIP, kecelakaan kerja yang dialami perawat seperti diludahi, dipukul, ditendang dan penghinaan terhadap perawat sehingga menyebabkan perawat menjadi patah tangan, memar dan trauma. Banyak alasan yang dikemukakan oleh perawat, salah satunya yaitu karena mereka merasa kurang mengetahui risiko kecelakaan akibat kerja dalam melayani pasien dengan gangguan jiwa. Hingga saatini, perawat tidak tahu harus bersikap dan berperilaku bagaimana untuk menghindari terjadinya kecelakaan dalam bekerja dalam memberikan pelayanan kesehatan jiwa.

Berdasarkan hasil studi di atas, dalam menerapkan keselamatan diri perawat melayani pasien gangguanjiwa yang berisiko terhadap keselamatan kerja baik secara fisik maupun secara mental sehingga dalam hal ini peneliti tertarik untuk melakukan penelitian tentang faktor yang berhubungan dengan kecelakaan kerja pada perawat di rumah sakit jiwa tampan pekanbaru tahun 2015.

\section{HASIL DAN PEMBAHASAN}

\section{Hubungan umur dengan kecelakaan kerja.}

Hasil penelitian ini

menunjukan bahwa Umur yang $<34$ tidak pernah mengalami kecelakaan kerja yaitu 46 orang $(73,0 \%)$. Hasil uji statistik dengan uji chi square diperoleh $p$ value $0,000<0,05$ artinya terdapat hubungan yang signifikan antara Umur dengan kecelakaan kerja. Analisis keeratan kedua varaiabel didaptkan Odd Ratio (OR) 4,118 dengan Confidence Interval (CI) 95\% $1,915-8,885$ artinya umur $\geq 34$ tahun memberikan peluang 4 kali mengalami kecelakaan kerja dibandingkan dengan umur $<34$ tahun Depnaker RI. (1998) dalam helda menyatakan bahwa tenaga kerja yang masih muda mempunyai 
kemampuan kerja yang lebih baik dari pada tenaga kerja yang sudah tua. Hal ini berkaitan dengan berkurangnya kemampuan kerja dari tenaga kerja sejalan dengan pertambahan usia, karena perubahan pekerjaannya, termasuk cara pencegahan kecelakaan maupun mengindari kecelakaan saat ia melakukan pekerjaannya.

Menurut Hunter (1975) dalam Dhika (2011) Umur mempunyai pengaruh yang penting terhadap kejadian kecelakan kerja. Golongan umur tua mempunyai kecenderungan yang lebih tinngi untuk mengalami kecelakaan akibat kerja dibandingkan dengan golongan umur muda karena umur muda mempunyai reaksi dan kegesiatan yang lebih tingggi.

Berdasarkan uraian di atas peneliti menyimpulkan bahwa faktor umur dapat menimbulkan kecelakan keraja. Umur perawat 34 keatas rentan mengalami kecelakan kerja karena perawat berumur 34 kebawah lebih hati-hati dalam berkerja.

\section{Hubungan pengetahuan dengan kecelakaan kerja \\ Hasil penelitian ini}

menunjukkan bahwa pengetahuan yang tinggi tidak pernah mengalami kecelakaan kerja yaitu sebanyak 53 orang (67,1\%). Hasil uji statistik dengan uji chi square diperoleh $\mathrm{p}$ value $0,004<0,05$ artinya terdapat hubungan yang signifikan antara pengetahuan dengan kecelakaan kerja. Analisis keeratan kedua varaiabel didaptkan Odd Ratio (OR) 3,313 dengan Confidence Interval (CI) 95\% 1.5197,225 artinya pengetahuan yan 3 memberikan peluang 3 kali meıyaııı kecelakaan kerja dibandingkan dengan pengetahuan yang tinggi.

Pengetahuan merupakan hasil dari tahu dan ini terjadi setelah orang mengadakan pengindraan terhadap suatu objek tertentu. Pengindraan terhadap objek terjadi melalui indra manusia, yakni indra penglihatan, pendengaran, penciuman, rasa dan raba dengan sendiri. Sebagian besar pengetahuan manusia diperoleh melalui mata dan telinga. Pengetahuan atau kognitif merupakan domain yang sangat penting dalam membentuk tindakan seseorang (Notoadmojo, 2007).

Penelitian ini didukung oleh penelitian yang dilakukan Handayani (2011) tentang analisis perilaku keselamatan dan Kesehatan Kerja pada Perawat Rumah Sakit di Intalasi Gawat Darurat menyebutkan bahwa pengetahuan seorang perawat rumah sakit yang bekerja di instalasi gawat darurat menjadi faktor utama dalam mencegah terjadinya kecelakaan akibat kerja. Pengetahuan perawat yang baik, mampu menghindari kecelakaan kerja seperti pemakaian Alat Pelindung Diri (APD) dalam melayani pasien.

Begitu juga penelitian yang dilakukan oleh Ayu (2012) tentang pengaruh penggunaan panduan keselamatan perawat terhadap perilaku kesehatan dan keselamatan kerja perawat di Rumah Sakit Siaga Raya menunjukkan bahwa ada hubungan yang signigikan antara pengetahuan perawat terhadap perilaku kesehatan dan keselamata kerja dengan $p$ value $0,012<0,05$.

Berdasarkan uraian di atas peneliti menyimpulkan bahwa faktor pengetahuan seseorang merupakan faktor utama dalam menentukan perilaku pengambilan keputusan untuk mencapai tujuan tertentu. Sehingga seseorang mampu menghindari kemungkinan buruk yang akan terjadi akibat dari tindakan yang diambil 
olehnya. Artinya, pengetahuan mempengaruhi perilaku seseorang untuk bertindak yang benar tanpa menimbulkan bahaya atau risiko terhadap kesehatan dan keselamatan dirinya dalam mengerjakan sesuatu.

\section{Hubungan sikap dengan kecelakaan kerja}

Hasil penelitian ini menunjukkan bahwa sikap yang baik tidak pernah mengalami kecelakaan kerja yaitu sebanyak 53 orang $(65,4 \%)$. Hasil uji statistik dengan uji chi square diperoleh $p$ value $0,011<0,05$ artinya terdapat hubungan yang signifikan antara sikap dengan kecelakaan kerja. Analisis keeratan kedua varaiabel didaptkan Odd Ratio (OR) 2,839 dengan Confidence Interval (CI) 95\% 1,300-6,199 artinya sikap yang kurang baik memberikan peluang 3 kali mengalami kecelakaan kerja dibandingkan dengan sikap yang baik.

Sikap merupakan suatu reaksi atau respon yang masih tertutup dari seseorang terhadap stimulus atau objek. Sikap secara nyata menunjukkan konotasi adanya kesesuaian reaksi terhadap stimulus tertentu yang dalam kehidupan sehari-hari merupakan reaksi yang bersifat emosional terhadap stimulus sosial (Notoadmodjo, 2007).

Sebagaimana hasil penelitian ini, sebagian besar perawat bersikap baik dalam menjaga kesehatan dan keselamatan dirinya selama melayani pasien jiwa. Hal ini dapat diketahui, bahwa perawat yang mampu bersikap denga baik sebagian besar tidak mengalami kecelakaan akibat kerja selama bekerja di rumah sakit jiwa.

Penelitian ini didukung oleh penelitian yang dilakukan Handayani (2011) tentang analisis perilaku keselamatan dan Kesehatan Kerja pada Perawat Rumah Sakit di Intalasi Gawat Darurat menyebutkan bahwa sikap dan pengetahuan seorang perawat rumah sakit yang bekerja di instalasi gawat darurat menjadi faktor utama dalam mencegah terjadinya kecelakaan akibat kerja. Faktor sikap yang baik dimiliki oleh seorang perawat, mampu menghindari kecelakaan kerja seperti mengahargai kebutuhan pasien, berkomunikasi yang baik, dan pemakaian Alat Pelindung Diri (APD) dalam melayani pasien.

Berdasarkan uraian di atas peneliti berasumsi bahwa, perilaku keselamatan kerja pada perawat dalam melayani pasien jiwa memerlukan sikap yang baik sehingga tidak terjadi pemicu timbulnya konflik antara pasien dengan perawat dalam memenuhi keabutuhannya baik fisik, mental maupun psikologis.

\section{Hubungan tindakan dengan kecelakaan kerja.}

Hasil penelitian ini menunjukkan bahwa tindakan yang baik tidak pernah mengalami kecelakaan kerja yaitu 49 orang $(68,1 \%)$. Hasil uji statistik dengan uji chi square diperoleh $\mathrm{p}$ value $0,005<$ 0,05 artinya terdapat hubungan yang signifikan antara tindakan dengan kecelakan kerja. Analisis keeratan kedua varaiabel didaptkan Odd Ratio (OR) 3,089 dengan Confidence Interval (CI) 95\% 1,452-6,572 artinya tindakan yang kurang baik memberikan peluang 3 kali mengalami kecelakaan kerja dibandingkan dengan tindakan yang baik.

Tindakan merupkan suatu proses yang dijalani manusia sebagai perilaku, dalam mencapai suatu tujuan. Pengukuran perilaku kesehatan dan keselamatan kerja perawat dalam bentuk tindakan atau perbuatan dapat dilakukan melalui observasi langsung (Notoatmodjo, 2007). 
Perilaku ksehatan dan
keselamtan kerja perawat dalam
Notoatmodjo (2010) menunjukkan
bawah perilaku merupakan tindakan
atau aktivitas dalam upaya mencegah
terjadinya penyakit akibat kerja dan
kecelakan akibat kerjadan kecelakan
akibat kerja. Perilaku manusia
manuasia mencakup aktivitas baik yang
dapat di amati maupun yang tidak dapat
diamti maupun yang tidak dapat
diamati oleh pihak luar sebagai sebagai
hasil daris proses pembelajaran. Perilaku dibedakan menjadi dua yaitu perilaku tertutup (conver behavior) dan perilaku terbuka (overt behavior). Perilaku tetutup adalah respon seseorang terhadap stimulus dalam bentuk terselubung atau tertutup yang masih terbatas pada perhatian, persepsi, pengetahuan, kesadaran, dan sikap yang terjadi pada orang menerima setimulus tersebut, dan belum dapat di amati secara jelas oleh orang lain.

Penelitian ini didukung oleh penelitian yang dilakukan Ayu (2012) tentang pengaruh penggunaan panduan keselamatan perawat terhadap perilaku kesehatan dan keselamatan kerja perawat di Rumah Sakit Siaga Raya menunjukkan bahwa ada hubungan yang signigikan antara tindakan perawat sesuai panduan terhadap perilaku kesehatan dan keselamata kerja dengan $p$ value $0,012<0,05$.

Berdasarkan uraian di atas peneliti menyimpulkan bahwa, kondisi kesehatan dan keselamatan kerja terjamin sehingga terhindar dari kecelakaan aktibat kerja dalam melayani pasien di rumah sakit jiwa diperlukan tindakan yang tepat dan sesuai dengan prosedur yang telah ditetapkan. Tindakan yang tepat dan sesuai prosedur, memudahkan seseorang bekerja dengan sehat dan selamat dilingkungan kerjanya.

\section{KESIMPULAN}

Faktor-faktor yang berhubungan dengan kecelakaan kerja adalah variabel umur ( $p$ value 0,000), pengetahuan $(p$ value 0,004$)$ sikap $(p$ value 0,014$)$, dan tindakan ( $p$ value $0,005)$.

\section{SARAN}

Disarankan kepada pihak rumah sakit melalui bagian diklat untuk mengadakan porgram K3RS dalam memberikan pelayaanan kesehatan jiwa di RS Jiwa Tampan Peknbaru.

\section{DAFTAR PUSTAKA}

Cahyono, D (2008). Membangun budaya keselamtan pasien dalam praktek kedoteran. Yogyakarta: Penerbit Kanisius.

Departemen Tenaga Kerja RI mengeluarkan keputusan Menteri tenaga Kerja Nomor 03/MEN/1998 tentang Tata cara Pelaporan dan Pemeriksaan Kecelakaan

Emji, J. (2014). Behavior Based Safety (BBS) / Keselamatan Berbasis Perilaku, Online, (http://www.hseinfo.com/2014/02/behaviorbased-safety-bbskeselamatan.html, diakses 13 April 2015.

Kementerian Kesehatan RI. (2009). Standar Keselamatan Kesehatan Kerja di Rumah Sakit. Kemenkes, Jakarta.

Kementerian Kesehatan RI. (2010). Standar Keselamatan Kesehatan Kerja di Rumah Sakit. Kemenkes, Jakarta.

Mangkunegara, S ((2002). Keselamatan dan kesehatan kerja. Edisi ke-3Jakarta: Erlangga. 
Meity, N (2012). Pengaruh Penggunaan panduan Keselamatan Pearawat Terhadap Perilaku Kesehatan dan Keselamatan Kerja di Rumah Sakit Siaga Raya Jakarta. FKM Universitas Indonesia

Notoatmodjo, S. (2007). Promosi Kesehatan dan imu Prilaku. Jakarta PT Rineka Cipta.

Sucipto. (2014). Keselamatan Dan Kesehatan Kerja. Yogyakarta Gosyeng publishing.

Sabarguna, B.S (2011). Manajemen Rumah Sakit, Jakarta: Salemba Medika

Sarbarguna, B.S (2006). Sistem Bantu Keputusan Untuk Keselamatan Pasien Rumah Sakit. Yogyakarta: Konsorsium Rumah Sakit Islam Jateng-DIY

Suma'mur. 1996. Hygiene Perusahaan dan Kesehatan Kerja. Jakarta : PT. Gunung Agung

Keliat, A.,Mustikasari.,Panjaitan, R.(1990). Gambaran Klien Perilaku Kekerasan Di Rumah Sakit Jiwa BogoR, (Online) (http://jurnal.jki.ui.ac.id/index.php/j ki/article/viewFile/135/pdf_123, diakses 27 Januari 2015)

Veny Elita, dkk (2013). Persepsi Perawat Tentang Perilaku Kekerasan Yang Dilakukan Pasien Di Ruang Rawat Inap Jiwa https://jurnal.www.google.com/sear ch?q=Veny+Elita $\% 2 \mathrm{C}+\mathrm{dkk}+\% 2820$ 13\%29. Diakses 28 maret 2015 